\title{
Studies of Sea-ice Motion in the Laptev Sea with the use of Satellite Remote Sensing and Numerical Modelling
}

\author{
Vitaly Yu. Alexandrov', Thomas Martin ${ }^{2}$, Josef S.Kolatschek ${ }^{3}$, Hajo Eicken ${ }^{4}$, Martin Kreyscher ${ }^{3}$, and Alexandr P. Makshtas ${ }^{5}$ \\ - 1 Nansen International Enviromental and Remote Sensing Center \\ Korpusnaya Str.18, 197110 St. Petersburg, Russia \\ Tel: +78122357493 , fax: +781223079 94, e-mail: nanseneonline. ru \\ 2 Institute fuer Meereskunde \\ Duesternbrookweg 20, 24105 Kiel, Germany \\ Tel: (0) 49431597 3870; fax:(0) 49431565 876, e-mail: tmartineifm.uni-kiel. de \\ 3 Alfred-Wegener-Institut fuer Polar- und Meeresforschung \\ Postfach 1201 61, D-27515, Bremerhaven, Germany \\ Tel: (0) 4714831 348; fax: (0) 4714831 149, e-mail: kolat sch@awi-bremerhaven. de \\ 4 Geophysical Institute, University of Alaska Fairbanks \\ 903 Koyukuk Dr., P.O. Box 757320 Fairbanks, AK 99775-7320, USA \\ Tel: (001) 907-474-7280; fax: (001) 907-474-7290, e-mail: hajo.eickenegi a a aska.edu
}

5 Arctic and Antarctic Research Institute

Beringa Str. 38, 199397, St. Petersburg, Russia

Tel: +7 81235233 52, Fax: +7 81235226 88, e-mail: makshtaseactor. ru

\begin{abstract}
Seasonal and interannual variability of ice drift in the Laptev Sea and ice exchange with the Arctic Ocean have been investigated using remote sensing data, a large-scale dynamic-thermodynamic numerical sea ice model and semi-empirical method. During the period 1979 - 1995 sea ice was exported from the Laptev Sea with maximum export occuring in February and minimum in August. The average winter ice outflow during this period was equal to 482700 km2. Estimates of ice exchange between the northern and southern parts of the Laptev Sea during the period 1936 to 1996 exhibited a strong interannual variability, but did not reveal significant trends.
\end{abstract}

\section{INTRODUCTION}

The Laptev Sea is a major source area for sea ice in the Eurasian sector of the Arctic Ocean [1]. The average ice export from the Laptev Sea is more than the combined export from the Barents, Kara, East Siberian and Chukchi Seas [2]. Previous studies revealed that during a major part of the year (from September/October to June) sea ice is exported from the Laptev Sea. In summer (July to September) ice circulation is more complex and sea-ice exchange with the Arctic Basin varies significantly during different years [3]. SSM/̄-derived ice velocity fields support the notion that the Transpolar Drift is supplied primarily from the Laptev and East-Siberian Seas [4].

\section{METHODS OF SATELLITE DATA ANALYSIS AND NUMERICAL MODELLING}

The sea-ice circulation in the Laptev Sea was studied based on the analysis of remote-sensing data, with ice velocity fields derived from passive-microwave data (SSM/I) and Russian "Okean" radar data for two winters (1987 - 1988 and 1994 - 1995). Giant ice floes were tracked from sequential "Okean" images in interactive mode for time intervals varied from 3 days to seven months. 48 and 27 drift patterns were retrieved for the winters 1987-1988 and 1994-1995, respectively. Large-scale ice drift patterns have been determined from $85.5 \mathrm{GHz}$ brightness temperature data on a $12.5 \mathrm{~km}$ Grid. The ice drift velocity was automatically derived for each 3-day period by matching large features on successive images based on a maximum-likelihood correlation technique [5]. 121 scenes were processed for the winter of $1987 / 1988$ and 125 for the winter 1994/1995.

A large-scale dynamic-thermodynamic sea-ice model [6], validated with these datasets, was employed for ice-circulation studies in the Laptev Sea from 1979 to 1995. The computations were performed on a regular grid with a spacing of $110 \mathrm{~km}$. A semi-empirical dependence between ice outflow and the average monthly gradients of atmospheric pressure from the polar stations Kotelnyy and Cape Chelyuskin [4] was used for climatological studies of sea-ice exchange between the southern and northern parts of the Laptev Sea for the period 1936 to 1996. 


\section{RESULTS}

The trajectories of ice floes, retrieved from successive "Okean" images, and simulated with dynamicthermodynamic model for the winter 1987 - 1988 correspond relatively well (Fig. 1). Drift patterns were also simulated for the same periods as the available "Okean" and SSM/I data. The exemplary results for the period from January 10 to January 30, 1988 are shown in Fig. 2. In the central part of the Laptev Sea ice drift velocities and directions, derived from the different sources coincide rather well, but near the coast difference between estimates increase. The comparison of SSM/1-derived and model ice fluxes for the winters 1987 . 1988 and 1994 - 1995 showed good general agreement.

Estimates of the average seasonal cycles of the areal ice fluxes (1979 to 1995) showed, that the total net ice flux out of the Laptev Sea reached maximum values in February and a minimum attained in July-August (Fig. 3). Through the northern boundary sea ice was imported to the Laptev Sea only during the summer months until September.

Total areal ice fluxes for the winter (October to May) and summer (June to September) periods for the years 1979 to 1995 are shown in Fig. 4. The average total ice export during winter amounted $482700 \mathrm{~km} 2$ and the average ice export through the northern boundary - to $492000 \mathrm{~km} \mathrm{2}$. During summer ice was also predominantly exported from the Laptev Sea, but through the northern boundary ice import prevailed. The average annual ice area, exported from the Laptev Sea in the period 1990 - 1995 increased by $9.1 \%$ as compared to that of 1979 to 1989 . We think, that the decrease in perennial ice area in this period $[7,8]$ is a result of enhanced northward advection of ice. Our results demonstrates that the balance of ice export from the Laptev Sea through its northern and eastern boundaries is closely coupled to the alternations of ice circulation in the Arctic Basin between cyclonic and anticyclonic regimes according to [9].

The annual average ice export from the southern Laptev Sea during the period 1937 - 1995 exhibited a strong interannual variability, with a mean value of about 300000 $\mathrm{km} 2$ /year and a well pronounced minimum in 1957. The time series does not indicate any significant climatological trend during the last 60 years (Fig. 5).

\section{CONCLUSION}

The total ice outflow from the Laptev Sea dominated all year round in the period 1979 - 1995 with maximum value in February and minimum in August. At its northern boundary ice outflow dominated from October until March and ice inflow from June to September. Average winter ice outflow was equal to $482700 \mathrm{~km} 2$. The export of sea ice through the eastern boundary of the Laptev Sea is of considerable importance for the East Siberian Sea and the Arctic Ocean.
Climatological studies of sea ice outflow from the southern part of the Laptev Sea does not indicate any significant trend during the last 60 years. The average sea ice export during the period 1936 - 1995 was equal to $309000 \mathrm{~km} 2$.

\section{ACKNOWLEDGMENTS}

We are grateful for financial support by the German Ministry of Research (BMBF) under the grant "System Laptewsee". We are grateful to P.N. Svyashchennikov for preparation of long-term meteorological data. "Okean" images were provided by the Ice Centre of the AARI (St. Petersburg). SSMR and SSM/I images were provided by the National Snow and Ice Data Center, Boulder, Colorado.

\section{REFERENCES}

[1] H.Eicken, E.Reimnitz, V.Alexandrov, Th.Martin, H.Kassens, and Th.Viehoff, "Sea - ice processes in the Laptev Sea and their importance for ice rafting of sediments", Continental Shelf Research, vol.17, 2, 1997, pp.205-233.

[2] L.A.Timokhov, "Regional characteristics of the Laptev and the East Siberian Seas: climate, topography, ice phases, thermohaline regime, circulation", in Russian-German Cooperation in the Siberian Shelf Seas: Geo-System Laptev-Sea, Ber. Polarforsch., vol.144, 1994, pp. 15 - 31 .

[3] Z.M.Gudkovich. and A.Ya.Nikolaeva, "Ice drift in the Arctic Seas and its connection with the ice cover of the Soviet Arctic Seas (in Russian)", Trudy Arkt. I Antarkt. Inst., vol.104, 1963, 186pp.

[4] W.J.Emery, C.W.Fowler, and J.A.Maslanik, "Satellite-derived maps of Arctic and Antarctic sea ice motion: 1988 to 1994 ", J. Geophys. Res., 24, 8, 1997 , pp.897-900.

[5] Th.Martin, and E.Augstein, "Large-scale drift of Arctic sea ice retrieved from passive microwave satellite data" in press.

[6] M.Harder, P.Lemke, and M.Hilmer, "Simulations of sea ice transport throught Fram Strait: Natural variability and sensitivity to forcing", in press.

[7] O.M.Johannessen, M.W. Miles, and E. Bjorgo, "The Arctic's shrinking sea ice”, Nature, vol.376, 1995, pp.126 $-127$.

[8] J.A.Maslanik, M.C.Serreze, and R.G. Barry, "Recent decreases in Arctic summer ice cover and linkages to atmospheric circulation anomalies", Geophys. Res. Lett., 23, 13, 1996, pp.1677 - 1680 .

[9] A.Yu.Proshutinsky, and M.A.Johnson, "Two circulation regimes of the wind-driven Arctic Ocean", J. Geophys. Res., vol.102, C6, 1997, pp.12493 - 12514. 


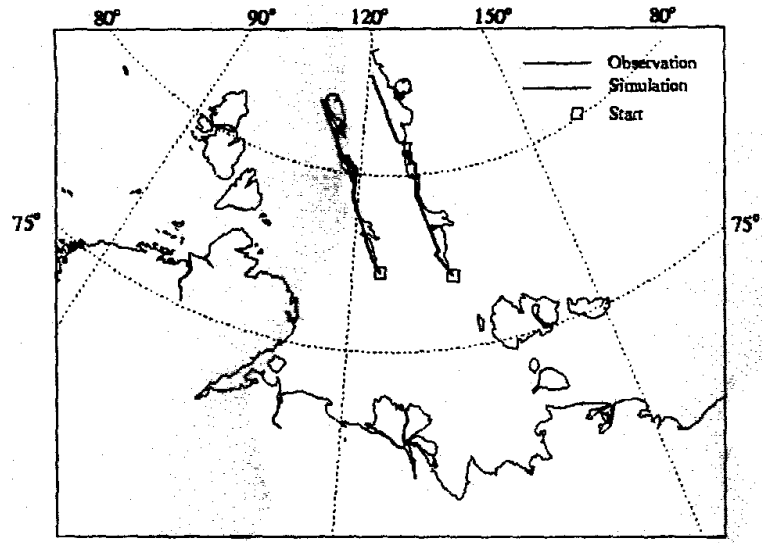

Fig. 1. Comparison of satellite-derived and calculated trajectories of giant ice floes in the central part of the Laptev Sea for the period October 28, 1987 - May 6, 1988.
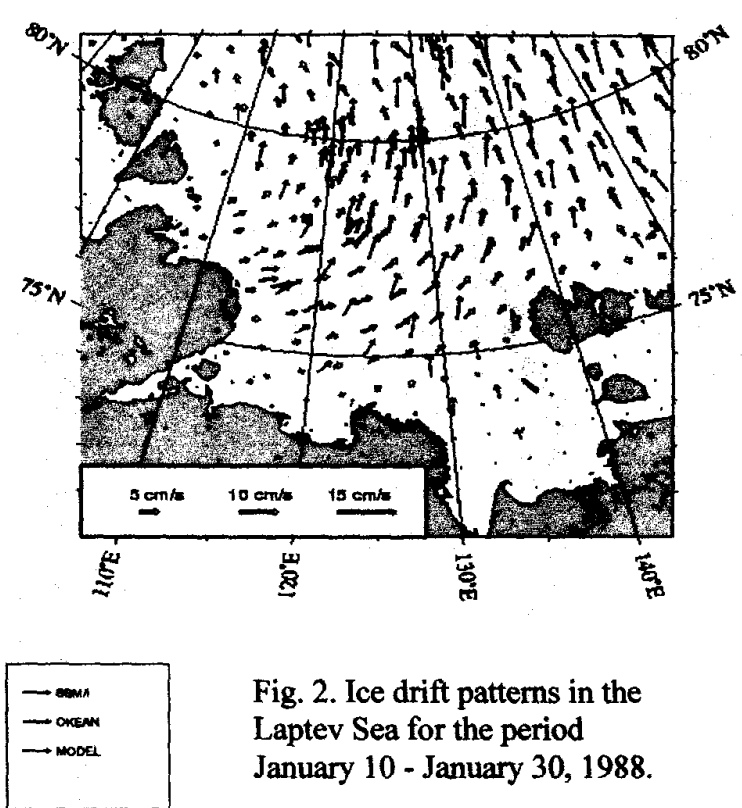

Fig. 2. Ice drift patterns in the Laptev Sea for the period January 10 - January 30, 1988.

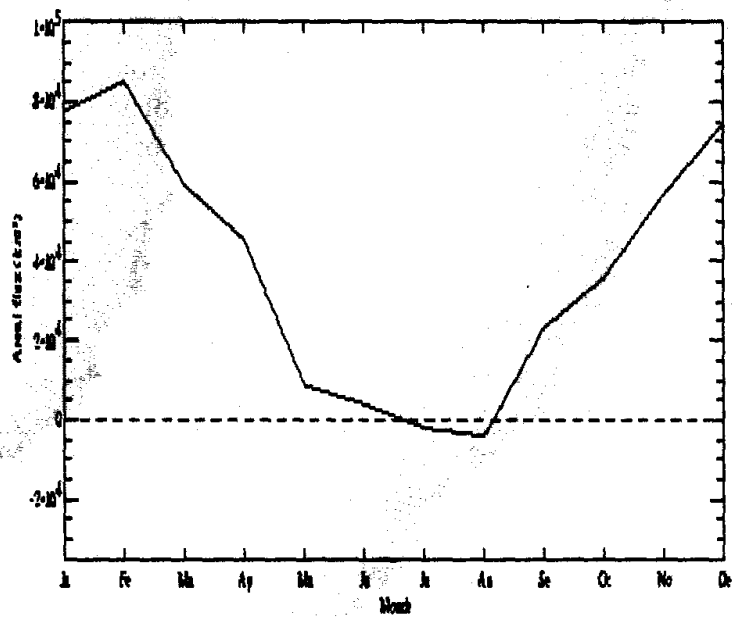

Fig. 3. Average total areal flux for the different months during the period 1979 - 1995 , estimated from model calculations

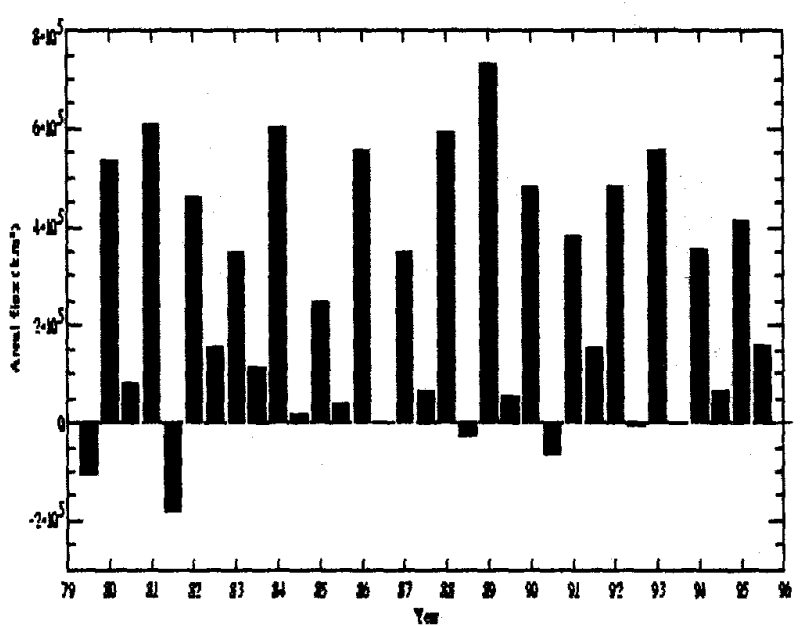

Fig. 4. Total areal ice flux for winters (light boxes) and summers (dark boxes) during the period 1979 1995

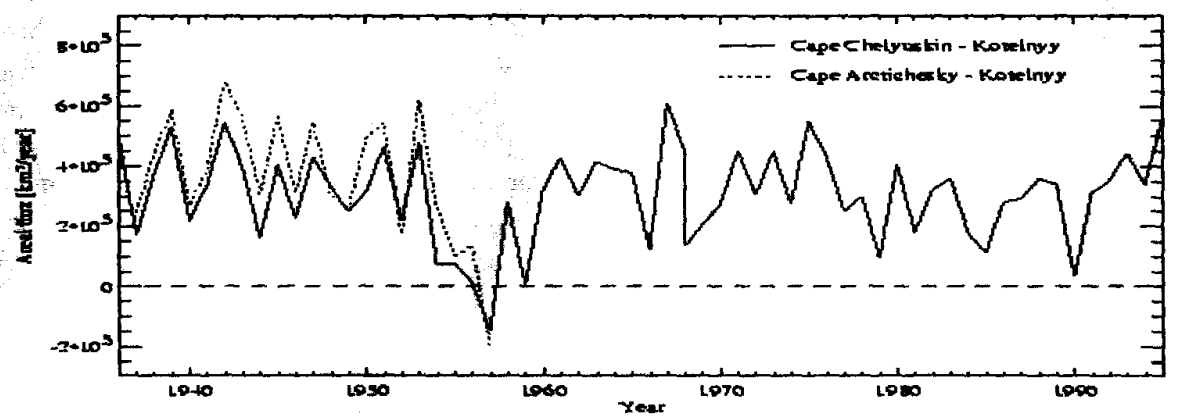

Fig. 5. Interannual variability of the sea ice export from the southern part of the Laptev Sea for the period 1936-1995 